\title{
Analyzing procedural equity in government-led community-based forest management
}

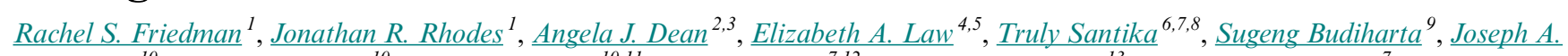

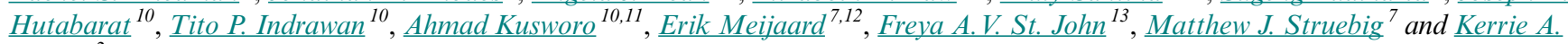 \\ Wilson $^{2}$
}

\begin{abstract}
Participatory approaches to forest management have been promoted as a means of returning rights historically removed, and as a way of managing natural resources sustainably, fairly, and to improve livelihoods in communities. Top-down models of community-based forest management take the perspective that if people feel ownership over, have a voice in decisions about, and can benefit from surrounding ecosystems, then they will be motivated to maintain and protect them. However, even participatory approaches, such as community-based forest management, may not always result in clear positive outcomes for involvement in decision making and forest conservation. We examine whether an Indonesian government initiative for community-based forest management was positively associated with community members' participation in local decision making and support for conservation and sustainable management of forest resources, in the context of state-owned lands. We used household questionnaire data to compare villages with and without a community forest, and community forests over time in a case study region of West Kalimantan. Analyzing forest visitations, conservation support, and indicators of procedural equity, we found no consistent association between having a community forest and higher levels of participation in decision making or household support for forest conservation. However, well-being indicators were positively associated with more active participation. The level of support for forest conservation was also positively related to households' leadership in village institutions and higher levels of well-being, particularly subjective well-being, land tenure, and material wealth. These social-demographic factors are important considerations when designing and implementing community-based forest management, which strives for fair and just decision-making processes along with forest conservation. The findings highlight how existing socioeconomic contexts factor into local institutions, and that accounting for these in program design and implementation may help address existing social inequalities that influence achieving joint social and ecological objectives.
\end{abstract}

Key Words: community-based forest management; conservation; environmental decision making; Indonesia; participation; social equity

\section{INTRODUCTION}

Loss and degradation of tropical forests, particularly in parts of Southeast Asia, are major concerns as countries develop and extract more resources from forests (Austin et al. 2017). To tackle this challenge, a variety of approaches to restore, maintain, and conserve forest ecosystems have been pursued. Participatory approaches, i.e., natural resources management programs in which local stakeholders are involved in decision making and/or management (FAO 2011, Gilmour 2016), in theory offer opportunities for both people and planet to benefit (Kellert et al. 2000, Agrawal and Gupta 2005, Gilmour 2016). These approaches assume that if local people have a voice in decisions about and can benefit from surrounding ecosystems, then they will feel incentivized to maintain and protect them (Schreckenberg et al. 2006, FAO 2011). Community participation in forest management is also considered a desirable end goal in its own right as part of democratizing environmental governance (Charnley and Poe 2007, Baker and Chapin 2018).
However, these broad social and ecological objectives do not always align, and there are diverse motivations for integrating biodiversity conservation, or the maintenance of habitats and biodiversity, and procedural social equity, which deals with fairness of process and involves inclusion, representation, and participation of individuals and groups in decision making (McDermott et al. 2013, Law et al. 2018). There are both practical and ethical rationales at play: including the utilitarian notion that procedural equity allows for diverse interests and values to be represented and defended (Gustavsson et al. 2014), and the normative notion that participants should feel they've been consulted, allowed a voice, and had the freedom to contribute (Smith and McDonough 2001, Martin et al. 2014). It is possible to articulate different aspects of procedural equity by looking at who participates or is excluded, to what extent, and how accepted the process is.

Community-based forest management (CFM) is a participatory approach often heralded in the literature as achieving win-win

\footnotetext{
${ }^{1}$ School of Earth and Environmental Sciences, University of Queensland, Saint Lucia, Queensland, Australia, ${ }^{2}$ Institute for Future Environments, Queensland University of Technology, Brisbane, Queensland, Australia, ${ }^{3}$ School of Biology and Environmental Science, Queensland University of Technology, Brisbane, Queensland, Australia, ${ }^{4}$ School of Biological Sciences, University of Queensland, Saint Lucia, Queensland, Australia, ${ }^{5}$ Norwegian Institute for Nature Research (NINA), Trondheim, Norway, ${ }^{6}$ Natural Resources Institute (NRI), University of Greenwich, Chatham Maritime, UK, ${ }^{7}$ Durrell Institute of Conservation and Ecology (DICE), School of Anthropology and Conservation, University of Kent, Canterbury, UK, ${ }^{8}$ Centre of Excellence for Environmental Decisions (CEED), University of Queensland, Brisbane, Australia, ${ }^{9}$ Purwodadi Botanic Garden, Indonesian Institute of Sciences (LIPI), Pasuruan, Indonesia, ${ }^{10}$ Fauna \& Flora International - Indonesia Programme, Jakarta, Indonesia, ${ }^{11}$ The Nature Conservancy - Indonesia Programme, Jakarta, Indonesia, ${ }^{12}$ Borneo Futures, Bandar Seri Begawan, Brunei, ${ }^{13}$ School of Natural Sciences, Bangor University, Bangor, UK
} 
social and ecological outcomes, including reduced deforestation rates, forest rehabilitation, and improved human well-being and social equity (De Royer et al. 2018). It often aspires to bring together participatory decision-making processes, rights recognition, and community engagement in management, to achieve more equitable natural resources governance (Agrawal et al. 2008, Raik et al. 2008). The general logic uniting the social and ecological elements of CFM is that community participation encourages a sense of ownership over the rights, rules, and decisions over forest resources, which in turn fosters social equity and builds stronger support for forest conservation (Baker and Chapin 2018). Previous studies on CFM offer evidence of community engagement through fair procedures (e.g., Agrawal 2001), recognition of rights and interests of marginal groups (Charnley and Poe 2007), and sustainable forest management (e.g., Santika et al. 2017). However, because CFM can be implemented in different land-tenure contexts, from privately owned forests to state-controlled yet locally managed (Gilmour 2016), how participation is treated can vary substantially between cases and across geographies.

Although local participation is often conceptualized as partaking in forest management activities, it has also been studied in terms of involvement in different stages of decision making and can be broken down further to distinguish passive, active, and interactive levels of community member engagement (Baker and Chapin 2018, van Noordwijk 2019). Multiple studies have highlighted the complexity of assessing participation, due to the complexity in defining what qualifies as an acceptable level of participation, what constitutes just procedure, and what variables affect participation (Reed 2008, Vimal et al. 2018). Within biodiversity conservation research, procedural equity is often framed simply as generic participation without further qualification (Friedman et al. 2018).

Studies on CFM also examine factors that influence participation in planning or implementing management actions, and what groups of people may or may not be involved. Social-demographic variables, such as caste, ethnicity, gender, age, wealth, dependence on forests, and land tenure are found to affect participation (Subedi and Timilsina 2016, Negi et al. 2018). Previous research highlights how exclusion of socially marginalized groups (Maskey et al. 2006, Chhetri et al. 2013, Ward et al. 2018) and cases of elite capture cuts across cases of community-based natural resources management internationally (Saito-Jensen et al. 2010, Persha and Andersson 2014). For instance, a Nepalese case study found wealthier and better-connected individuals were more likely to participate in community forest user groups (Agrawal and Gupta 2005).

Most of these studies examined variation in the participation in management activities within localities already engaged in CFM. However, it is also important to examine whether the community forest program itself (versus noncommunity forest) influences the nature of participation. We expand the scope of previous analyses and investigate the nature of participation in local decision-making institutions by community members in villages with versus without CFM. Though critical elements of CFM, participation in the process of acquiring forest rights and the development of specific management interventions are not analyzed in this study.

There is also the outstanding question of whether participation is a critical factor for achieving forest conservation and sustainable resources management. Studies have suggested that local participation is important for successfully addressing environmental problems (Reed 2008), in part because proximity to and dependence on forests likely drive responsible forest use (Charnley and Poe 2007). Others have suggested that involving local users in forest decision-making processes improves social equity and efficiency, which in turn also improves ecological sustainability (Ostrom 1990, Agrawal and Gupta 2005). However, the empirical evidence to support links between improved social equity and participation, and forest conservation and sustainable management remains limited, without studies presenting a strong case in either direction (Pagdee et al. 2006, Baynes et al. 2015).

Despite the lack of evidence, the notion that local stakeholders with responsibility for forests will sustainably manage forest resources is one that persists in both applied and academic discourses on CFM (De Royer et al. 2018). There is considerable need to examine the connections between CFM programs, the extent of local participation in decision-making processes, and implications for forest use and conservation. This study aims to improve our understanding of these relationships through two main questions: (1) is there a positive association between the level of participation in local decision-making processes and the presence of CFM (and what are the procedural equity implications); and (2) is greater participation positively associated with sustainable forest use and conservation support? We test the following hypotheses related to procedural equity and conservation (Fig. 1):

Fig. 1. Model conceptualization of simple theory of change for community-based forest management (CFM), connecting participation, procedural equity, and conservation support (solid arrows). Other factors that arise in the literature, including forest use and socioeconomic well-being are included with dashed arrows, denoting their hypothesized relationships with procedure and forest conservation.

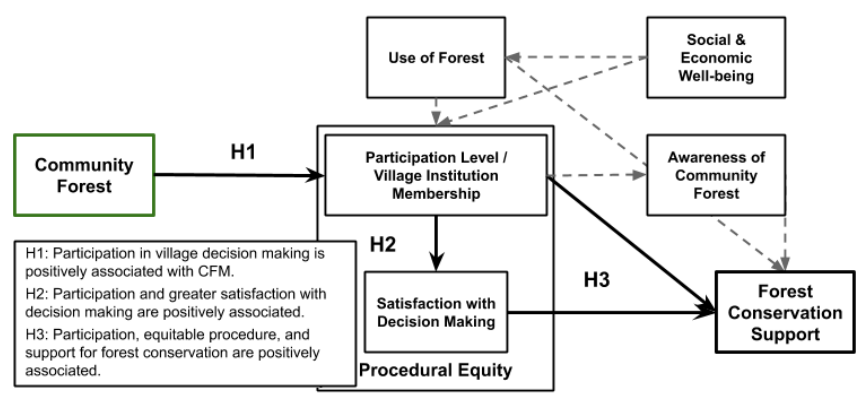

- H1: a higher level of local participation in village decision making is positively associated with the presence of CFM;

- H2: higher levels of household participation and greater satisfaction with decision-making processes are positively associated; and

- H3: higher levels of household participation, equitable procedure, and strong support for forest conservation are positively associated.

We use a regional case study in West Kalimantan, Indonesia to compare the patterns of participation in villages with and without community forests. This choice of case study allowed us to explore 
fundamental questions of participation in an approach to CFM that is government-led. As such, the findings offer lessons both for expansion of this approach in Indonesia, and for countries instituting a similar model of CFM, particularly in Southeast Asia (Fisher 1999, Adger et al. 2006, Gilmour 2016), while recognizing that in practice, contextual factors distinguish the experiences of different CFM initiatives.

\section{METHODS}

\section{Case study in Indonesia}

Natural forests make up nearly half of the land area in Indonesia, and simultaneously face severe threats from plantation, logging, and mining industries, (Royo and Wells 2012, Gaveau et al. 2016), as well as smallholder agriculture (Austin et al. 2019). Forests also represent the struggle for rights and recognition of local people in Indonesia. Between 1945 (independence) and 1998 (reformation), there was fierce state control and exclusion of local communities from forested lands (Colchester 2003). The allocation of forests for timber extraction, as well as for protected areas, resulted in displaced local communities, mass transmigrations, and exclusion from access and usufruct rights to land and forests (Colchester 2003). Since Indonesia's decentralization reforms began in 1998, the locus of authority for forest-related decisions has shifted from the national level established under the 1967 Basic Forestry Law, to vacillating between provincial and district levels (Clerc 2012).

As part of the decentralization reforms, CFM has enabled community-level governing bodies to acquire forest use rights and management responsibilities (Brockhaus et al. 2012, Ardiansyah et al. 2015). Community-based forest management in Indonesia has embraced elements of a bottom-up approach, by promoting a return of rights to access forests and supporting the notion that local communities know best how to manage natural resources, while retaining elements of a top-down approach in which compliance and monitoring are essential to ensure outcomes. Forest estate ownership remains with the state, which has designated the land for productive uses like plantations, timber extraction, or habitat protection (Santika et al. 2019). Similarly, forest management units (Kesatuan Pengelolaan Hutan, KPH) are responsible for implementing forest policy and coordinating with communities at the local level, while still falling under the jurisdiction of the provincial government (Sahide et al. 2016, Fisher et al. 2017).

Community-based forest management in Indonesia has expanded rapidly, from fewer than half a million hectares prior to 2008 to 4.2 million hectares in 2020 , but falls far short of the governmentset target of 12.7 million hectares $(10 \%$ of Indonesia's entire forest estate) by 2019 (Fisher et al. 2018; http://pkps.menlhk.go.id/ \#statistik). Existing social forestry policies, including Hutan Desa (HD), Hutan Kemasyarakatan (HKm), and Hutan Tanaman Rakyat (HTR), were established under the Forestry Law No. 41/1999 in 2007, updated in 2008 (Siscawati et al. 2017), and extended and streamlined under recent policy (Royo and Wells 2012, Jewitt et al. 2014). In this study, we focus on the predominant type of social forest, Hutan Desa, which covers 1.7 million hectares as of 2020 (http://pkps.menlhk.go.id/\#statistik). Its stated aims are to conserve forest resources, fill the forest management gap, support livelihoods, alleviate poverty, and empower communities (RI 2014, MEF 2016, De Royer et al. 2018).

Villages electing to apply for a Hutan Desa permit must establish a management committee (lembaga pengololaan hutan desa, LPHD) as part of the existing village governing body (De Royer et al. 2018). The LPHD, typically with the assistance of an external conservation NGO or donor, proposes a management area to the national Ministry of Environment and Forestry, and applies for the management permit from the provincial Department of Forestry. This process includes delineating the borders of the Hutan Desa, surveying and patrolling forest areas, and developing a management plan for forest resources for the 35 -year permit duration. The activities permitted under the Hutan Desa management plan (e.g., cultivation, extraction of nontimber forest products, payment for ecosystem services, or limited timber extraction) are determined by the ministry zoning of forested lands (e.g., production, limited production, watershed protection; MEF 2016). In theory, the village institution ensures all community members have rights to the Hutan Desa and are able to access benefits from sustainable uses of the forest (De Royer et al. 2018).

\section{Data collection}

The study design we employed allowed for comparison of villages with and without Hutan Desa, as well as before and after comparisons for a subset of Hutan Desa villages. Data were collected using a household survey carried out in 10 forest-based communities in the regencies of Ketapang and Kapuas Hulu, West Kalimantan (Fig. 2; Table 1) from April through June 2017. Villages with Hutan Desa were statistically matched with control villages without Hutan Desa based on geographic location, biophysical variables (e.g., land-use type and history), and demographic indicators (Appendix 1). In each village, 20-33\% of the households (total $n=1287$ ) were included in the survey using a random systematic sample following Cahyat et al. (2007). Data collection was conducted in Indonesian (or local dialect as needed) by trained enumerators. Panel study data exist for a subset of five Hutan Desa villages also surveyed prior to permitting/ implementation ( $\mathrm{n}=458$ households with surveys in both 2012 and 2017). At the time of study, all Hutan Desa villages had been operating as such since the baseline survey in 2012. Based on the government database of social forestry applications and approvals (http://pkps.menlhk.go.id/\#statistik), none of the control villages were preparing applications for Hutan Desa or other social forestry permits.

The questionnaire was based on Gönner et al.'s (2007) nested spheres of poverty (NESP) concept, which was developed to examine multidimensional poverty in forested areas of East Kalimantan and has since been deployed elsewhere in Indonesia. The questionnaire measured six aspects of well-being: social, political, economic, wealth, knowledge, and subjective wellbeing. Values for these aspects used in the analysis were based on the threshold calculations outlined in the NESP guidelines and reflected low/critical, medium, and good/prosperous conditions (Cahyat et al. 2007). These different aspects of well-being could affect capacity for engagement in broader village life, such as participation in local decision-making processes. We also included questions on forest visits and resource use, involvement in and satisfaction with village decision making, and support for forest 
Table 1. Study villages and attributes. Dominant livelihood was determined using Indonesia's national census data (PODES) and is based on the primary livelihood sector and dominant concession type in a village (Santika et al. 2019). Forest type is based on the Ministry of Environment and Forestry classification of the forest estate and dictates what activities can occur.

\begin{tabular}{|c|c|c|c|}
\hline Regency & Village & Dominant Livelihood & Forest Types \\
\hline \multirow[t]{2}{*}{$\begin{array}{l}\text { Kapuas Hulu } \\
\text { (Hutan Desa }\end{array}$} & $\begin{array}{l}\text { Village HD1 } \\
(\mathrm{n}=29)\end{array}$ & Subsistence-based (swidden farming) & Limited production \\
\hline & $\begin{array}{l}\text { Village HD2 } \\
(\mathrm{n}=41)\end{array}$ & $\begin{array}{l}\text { Plantation outside concessions (mixed plantations, } \\
\text { agroforestry) }\end{array}$ & Watershed protection \\
\hline \multirow[t]{2}{*}{$\begin{array}{l}\text { Kapuas Hulu } \\
\text { (no Hutan Desa) }\end{array}$} & $\begin{array}{l}\text { Village NHD1 } \\
(\mathrm{n}=103)\end{array}$ & $\begin{array}{l}\text { Plantation outside concessions (mixed plantations, } \\
\text { agroforestry) }\end{array}$ & Limited production \\
\hline & $\begin{array}{l}\text { Village NHD2 } \\
(\mathrm{n}=32)\end{array}$ & Subsistence-based (swidden farming) & Watershed protection \\
\hline \multirow[t]{4}{*}{$\begin{array}{l}\text { Ketapang } \\
\text { (Hutan Desa) }\end{array}$} & $\begin{array}{l}\text { Village HD6 } \\
(\mathrm{n}=213)\end{array}$ & Plantation within oil palm concessions & Convertible production \\
\hline & $\begin{array}{l}\text { Village HD5 } \\
(\mathrm{n}=276)\end{array}$ & $\begin{array}{l}\text { Other sectors (incl. horticulture, aquaculture, livestock, } \\
\text { coastal fishing, commercial wet rice) }\end{array}$ & Limited production \\
\hline & $\begin{array}{l}\text { Village HD3 } \\
(\mathrm{n}=160)\end{array}$ & $\begin{array}{l}\text { Other sectors (incl. horticulture, aquaculture, livestock, } \\
\text { coastal fishing, commercial wet rice) }\end{array}$ & Convertible production \\
\hline & $\begin{array}{l}\text { Village HD4 } \\
(\mathrm{n}=252)\end{array}$ & Plantation within oil palm concessions & Limited production \\
\hline \multirow[t]{2}{*}{$\begin{array}{l}\text { Ketapang } \\
\text { (no Hutan Desa) }\end{array}$} & $\begin{array}{l}\text { Village NHD3 } \\
(\mathrm{n}=88)\end{array}$ & $\begin{array}{l}\text { Plantation outside concessions (mixed plantations, } \\
\text { agroforestry) }\end{array}$ & Permanent production \\
\hline & $\begin{array}{l}\text { Village NHD4 } \\
(\mathrm{n}=93)\end{array}$ & $\begin{array}{l}\text { Plantation outside concessions (mixed plantations, } \\
\text { agroforestry) }\end{array}$ & Permanent production \\
\hline
\end{tabular}

conservation (Table 2). Respondents for the questionnaire were given information about the study and provided written consent to participate. Human research ethics clearance was obtained through the University of Queensland (\#2016001332).

Fig. 2. Map of household questionnaire sites in West Kalimantan.

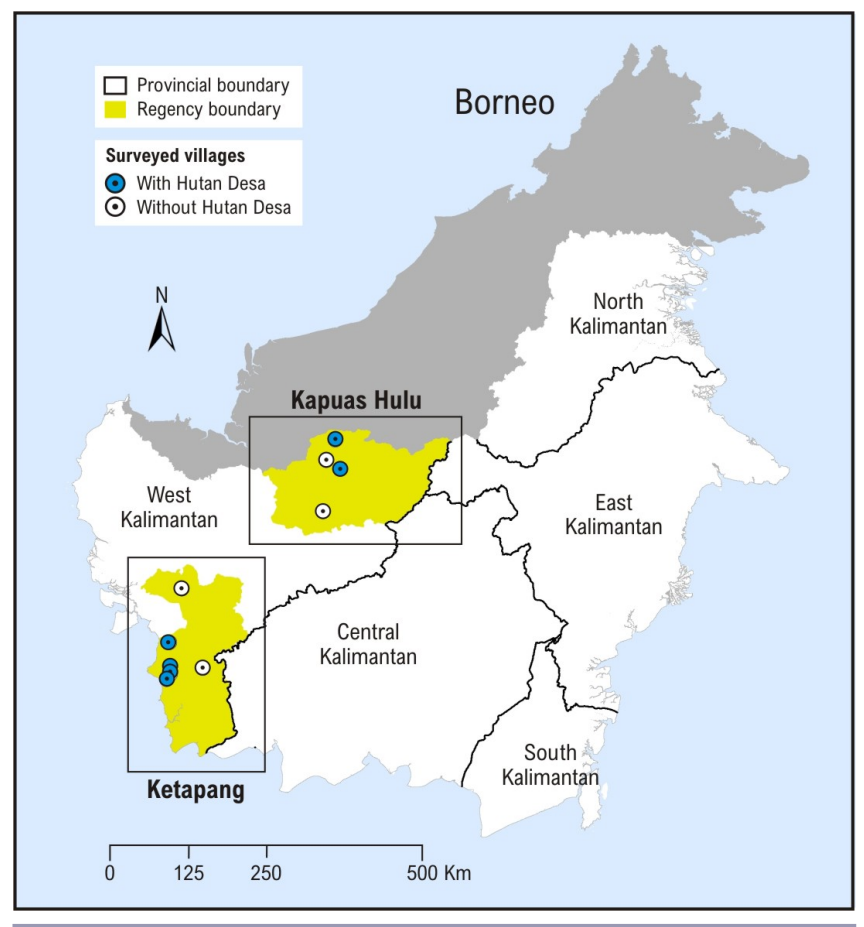

We included three measures of participation (Table 2): householdlevel participation in village meetings; membership in the village decision-making institution (lembaga desa); and satisfaction with level of participation in decision making. We included both the level of participation in village meetings and membership in the village institution as measures of participation because the variables represent two different aspects of social capital (Gurney et al. 2016): engagement and leadership, respectively, and convey different facets of participation. Our participation variables measured engagement in general village processes, as opposed to participation in Hutan Desa specific matters, to facilitate the comparison between villages with and without Hutan Desa. Because the Hutan Desa management committee was a subcommittee of the village institution, we assumed parallels between general and forest-specific institutions (see Appendix 2 for correlation matrices). We considered procedural equity a combination of the level and inclusivity of participation in village institutions and satisfaction with this level of participation.

\section{Data analysis}

All analyses were carried out using $\mathrm{R}$ version 3.4.4 (R Core Team 2018). We fitted a series of cumulative link mixed effects models using the Ordinal package (Christensen 2018), with participation in village decision making $(\mathrm{H} 1)$, procedural satisfaction $(\mathrm{H} 2)$, and forest conservation support $(\mathrm{H} 3)$ as the respective response variables. Mixed effects models were used because they allow for both village-level grouping (random effect) and predictor variables (Gelman and Hill 2007). Correlations were first calculated between well-being and participation measures, and then visualized using the ggcorrplot package (Kassambara 2018). For the Hutan Desa communities surveyed in both 2012 (preHutan Desa) and 2017, we calculated the change in participation levels, use of forest, and conservation support for each respondent and the mean change for each village, comparing the two years 
Table 2. Definitions of variables used in the study. Demographic variables including ethnic group and migrant status were also collected, but were not included as covariates because of the homogeneity within villages.

\begin{tabular}{|c|c|c|}
\hline Concept & Variable & Description \\
\hline Governance & Hutan Desa & $\begin{array}{l}\text { Variable indicates the presence of a Hutan Desa permit. } \\
\text { Categorical two levels: } 0=\text { without or } 1=\text { with a Hutan Desa permit. }\end{array}$ \\
\hline \multirow[t]{5}{*}{ Participation } & participation level & $\begin{array}{l}\text { Whenever a village meeting being held, how is the response of a member of this family? } 1=\text { seldom } \\
\text { attends meetings; } 2=\text { sometimes attends meetings, but rarely expresses opinions; } 3=\text { often attending } \\
\text { meetings and/or actively participating. }\end{array}$ \\
\hline & $\begin{array}{l}\text { institution } \\
\text { membership }\end{array}$ & Is anyone in your household a member of any village institution? $0=$ no; $1=$ yes. \\
\hline & procedural satisfaction & $\begin{array}{l}\text { You are satisfied with your household's level of participation in decision making about the Hutan } \\
\text { Desa (or general forest if Hutan Desa). } 1=\text { disagree; } 2=\text { neutral; } 3=\text { agree. }\end{array}$ \\
\hline & awareness of Hutan & Awareness of the Hutan Desastatus of respondent's community. \\
\hline & Desa & Categorical two levels: $0=$ uncertain/unaware; $1=$ aware of status. \\
\hline Forest Use & $\begin{array}{l}\text { forest use } \\
\text { dominant livelihoods }\end{array}$ & $\begin{array}{l}\text { Does any household member make regular forest trips (more than once a month)? } 1=\text { no; } 2=\text { yes. } \\
\text { Dominant livelihood based on primary sector in each village as shown in Table } 1 \text {. Categorical four } \\
\text { levels: plantation inside concession; plantation outside concession; subsistence based; other sectors } \\
\text { (reference category). }\end{array}$ \\
\hline Conservation Support & conservation support & $\begin{array}{l}\text { How is your support on forest protection and conservation in this } \\
\text { village? } 1 \text { = not supporting; } 2=\text { supporting if it provides benefits; } 3=\text { supporting. }\end{array}$ \\
\hline Indicators of & subjective well-being & (1) How was your well-being during the last year? $1=$ low; $2=$ average; $3=$ high. \\
\hline \multirow[t]{8}{*}{ Socioeconomic Well-being } & & $\begin{array}{l}\text { (2) Compared to other households in this village, how is the well-being of this household? } 1=\text { worse } \\
\text { than others; } 2=\text { same as others; } 3=\text { better than others. } \\
\text { (3) Do you think this family is already prosperous? } 1=\text { no; } 2=\text { in-between; } 3=\text { yes. } \\
\text { (4) How do you think about your household prosperity in future? } 1=\text { getting difficult; } 2=\text { stays the } \\
\text { same; } 3=\text { getting better. }\end{array}$ \\
\hline & material wealth & $\begin{array}{l}\text { (1) Does this family have: (a) toilet in the house? (b) outboard engine or motorbike/car? (c) chainsaw } \\
\text { or refrigerator? } 1=\text { no; } 2=\text { yes. } \\
\text { (2) Condition of house (observed). } 1=\text { below village standard; } 2=\text { standard (average); } 3=\text { above } \\
\text { village standard. }\end{array}$ \\
\hline & knowledge & $\begin{array}{l}\text { (3) Does this house have electricity? } 1=\text { no; } 2=\text { yes, but out of order; } 3=\text { yes and functioning. } \\
\text { (1) What is the highest level of education of adults in this family? } 1=\text { not completed elementary } \\
\text { school; } 2=\text { completed elementary or junior high school; } 3=\text { completed senior high school or higher. } \\
\text { (2) How is school attendance of children? } 1=\text { never attending; } 2=\text { sometimes attending; } 3=\text { always } \\
\text { attending. }\end{array}$ \\
\hline & & $\begin{array}{l}\text { (3) Has any household member ever attended training or a course? } 1=\text { no; } 2=\text { yes. } \\
\text { (4) Has any household member special skills that can generate income? (e.g., midwifery, shaman, } \\
\text { smithing). } 1=\text { no; } 2=\text { yes. }\end{array}$ \\
\hline & economic & $\begin{array}{l}\text { (1) Does any household member have a stable wage? } 1=\text { no; } 2=\text { yes. } \\
\text { (2) Was the rice harvest enough for household consumption during the last year? } 1=\text { not enough; } \\
2=\text { enough; } 3=\text { more than enough. } \\
\text { (3) Does any household member own valuable goods (e.g., savings in bank, credit union, gold)? } 1= \\
\text { no; } 2 \text { = yes. }\end{array}$ \\
\hline & social & $\begin{array}{l}\text { (1) What is the level of communal work (gotong royong) in this village? } 1=\text { weak: most people don't } \\
\text { participate/donate; } 2=\text { average: only a few don't participation/donate; } 3=\text { high: most participate. } \\
\text { (2) How is mutual trust in this village? } 1=\text { no trust (conflict); } 2=\text { average, some level of trust; } 3= \\
\text { strong mutual trust (unity). } \\
\text { (3) Were there any conflicts between villagers and outsiders during the last year? } 1=\text { yes, resulting in } \\
\text { material damage or people were wounded; } 2=\text { there was tension; } 3=\text { no conflicts. }\end{array}$ \\
\hline & political & $\begin{array}{l}\text { (1) During the last month have you gained information/news from any of the following media } \\
\text { sources: TV, radio, newspaper, district government announcements, mobile phone/social media. } 1= \\
\text { yes to one source; } 2 \text { = yes to more than one source. }\end{array}$ \\
\hline & & $\begin{array}{l}\text { (2) How is tenure of your land (swidden, paddy, and gardens)? } 1=\text { weak: no proof of tenure; } 2= \\
\text { average: small chance someone will take land; } 3=\text { strong: long-term security (certificate). }\end{array}$ \\
\hline Location & desa & Village name; included as random effect. Categorical 10 levels. \\
\hline
\end{tabular}

using paired t-tests and McNemar's Chi-Square tests for symmetry in count data. Models included village as a random effect to account for variations between villages. For each model, we also included well-being indicators and forest use as explanatory variables. We did not include ethnicity or migrant status as covariates because there was little within-village variation and thus it was accounted for when we controlled for village. Age and gender of respondents were also excluded from models because questions were answered from the perspective of the household.

We also investigated what factors were associated with forest use and community knowledge of the Hutan Desa in the villages with two additional generalized linear mixed models using the lmerTest package (Kuznetsova et al. 2017). Each included participation level, membership in the village institution, and procedural 
satisfaction as fixed effects, and forest use or awareness of the Hutan Desa as response variables.

\section{RESULTS}

\section{H1: community-based forest management is linked to greater participation in decision making}

We found no significant relationship between the Hutan Desa and higher levels of participation in village meetings, although in our samples, villages without a Hutan Desa permit showed slightly more active participation, and Hutan Desa communities had greater nonparticipation (Fig. 3). This finding is consistent with the comparison between 2012-2017, which found no significant pattern of change in level of participation since the introduction of a Hutan Desa in $2012(\mathrm{t}=-0.64$, $\mathrm{df}=456$, $\mathrm{p}$-value $=0.52$ ). Across all villages, most well-being metrics had significant positive associations with higher levels of household participation, suggesting involvement by the well-off members of a community (Fig. 4; Table 3). Wealth was the only well-being variable that was not significant. Furthermore, dominant livelihood of the village was a significant predictor of participation in village meetings: areas with plantations in concessions or practicing subsistence livelihoods showed higher participation, hinting that village context might affect how engaged households are in village institutions.

Fig. 3. Sankey diagram showing household-level participation village meetings by interventio, i.e., Hutan Desa versus no Hutan Desa. Villages with Hutan Desa have a greater proportion of respondents with nonattendance $(38.4 \%)$ or passive $(49.2 \%)$ participation in village meetings, compared to villages without a Hutan Desa, in which most respondents reported passive $(45.9 \%)$ or active $(27.5 \%)$ levels of participation. Produced using alluvial package in $\mathrm{R}$ (Bojanowski and Edwards 2016).

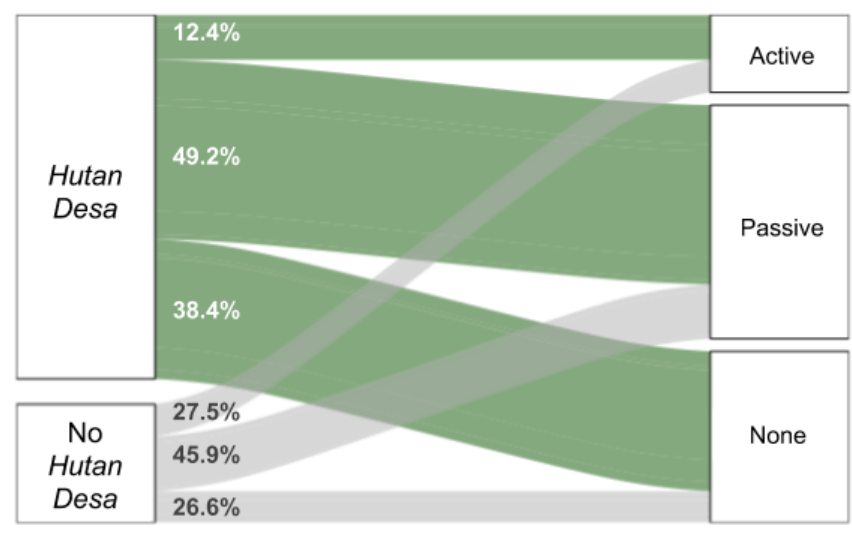

Intervention

Participation

H2: participation in decision making improves procedural equity Households in villages with a Hutan Desa had significantly lower household procedural satisfaction (Fig. 5; Table 3). There were also positive associations between household satisfaction with the decision-making procedure and being a member in a village institution, higher social, subjective, and economic well-being variables, and higher procedural satisfaction. When combined with the relationship between higher well-being and more active participation, these findings reveal potentially inequitable (or at least unrepresentative) local decision-making processes.

Fig. 4. Coefficient estimates from cumulative link mixed model with participation level as the response variable.

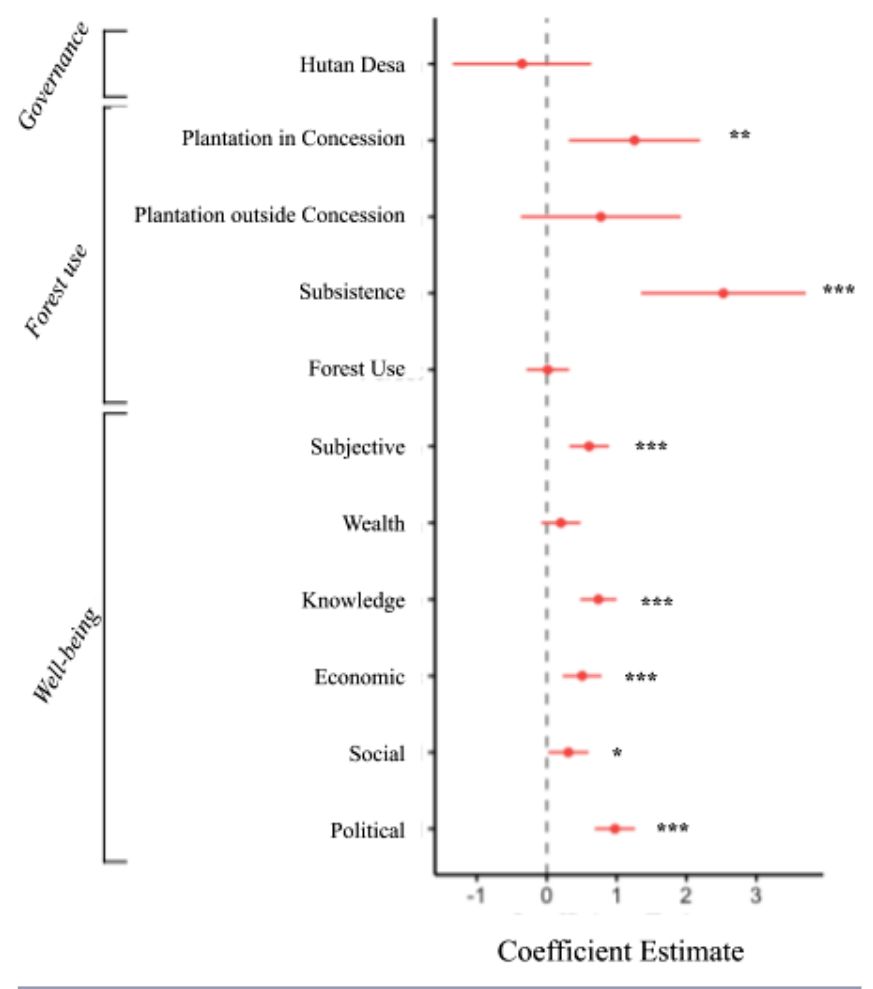

H3: greater participation is associated with stronger support for conservation

Membership in the village institution was positively and significantly associated with support for forest conservation (Fig. 6; Table 3). Furthermore, there were positive associations between higher economic, political, and subjective well-being variables and more support for forest conservation. This suggests that households with stable income sources, stronger land tenure, better access to media sources, and higher perceived prosperity were more supportive of forest conservation. Villages with Hutan Desa were negatively associated with support for conservation, which may indicate the conditionality of responses, i.e., that forest conservation is acceptable only if these respondents see a benefit. Considering Hutan Desa aims to improve livelihoods, it is reasonable that community members would expect returns for maintaining their forest. Where data were available at two timepoints, levels of conservation support increased between 2012 and $2017(\mathrm{t}=-4.60, \mathrm{df}=456, \mathrm{p}$-value $=5.44 \mathrm{e}-06)$. However, this may be a sign that support for conservation has increased in the region generally, rather than as a consequence of Hutan Desa, as both control and intervention sites have similar levels of conservation support in 2017 (Fig. 7). 
Table 3. Empirical results from full cumulative link mixed models response variables (a) level of participation in village meetings, (b) procedural satisfaction, and (c) conservation support. Note that the reference level for dominant livelihood is other sectors.

\begin{tabular}{|c|c|c|c|c|c|c|}
\hline \multirow[t]{2}{*}{ Independent Variable } & \multicolumn{2}{|c|}{ Participation Level } & \multicolumn{2}{|c|}{ Procedural Satisfaction } & \multicolumn{2}{|c|}{ Conservation Support } \\
\hline & Estimate & SE & Estimate & SE & Estimate & SE \\
\hline Hutan Desa & -0.35 & 0.51 & $-2.83^{* *}$ & 0.93 & $-3.36^{* *}$ & 1.26 \\
\hline Participation Level & NA & NA & $-0.23 *$ & 0.11 & 0.23 & 0.14 \\
\hline Institution Membership & NA & NA & $0.74 * * *$ & 0.22 & $0.61 *$ & 0.31 \\
\hline Procedural Satisfaction & NA & NA & NA & NA & $-0.28 *$ & 0.14 \\
\hline \multicolumn{7}{|l|}{ Dominant Livelihood:- } \\
\hline Plantation in Concession & $1.26 * *$ & 0.48 & 0.10 & 0.98 & 1.08 & 1.23 \\
\hline Plantation outside Concession & 0.77 & 0.58 & -1.46 & 1.11 & $-2.33^{\dagger}$ & 1.41 \\
\hline Subsistence & $2.53 * * *$ & 0.14 & -1.32 & 1.11 & -1.41 & 1.42 \\
\hline Forest Use & 0.014 & 0.16 & 0.19 & .16 & $0.37^{\dagger}$ & 0.22 \\
\hline Subjective Well-being & $0.57 * * *$ & 0.14 & $0.34 *$ & 0.14 & $0.93 * * *$ & 0.19 \\
\hline Wealth & 0.14 & 0.098 & -0.11 & 0.10 & -0.088 & 0.12 \\
\hline Knowledge & $0.42 * * *$ & 0.074 & 0.047 & 0.077 & -0.024 & 0.10 \\
\hline Political & $0.76^{* * *}$ & 0.11 & 0.11 & 0.11 & $0.47 * * *$ & 0.14 \\
\hline Social & $0.39 *$ & 0.19 & $0.61 * *$ & 0.21 & 0.27 & 0.26 \\
\hline Economic & $0.30^{* * *}$ & 0.083 & $0.19^{*}$ & 0.089 & $0.36^{*}$ & 0.14 \\
\hline
\end{tabular}

$p$ values $\dagger<0.1 *<0.05 * *<0.01 * * *<0.001 ;$ NA not included in the model. SE $=$ standard error.

Fig. 5. Coefficient estimates from cumulative link mixed model with procedural satisfaction as the response variable.

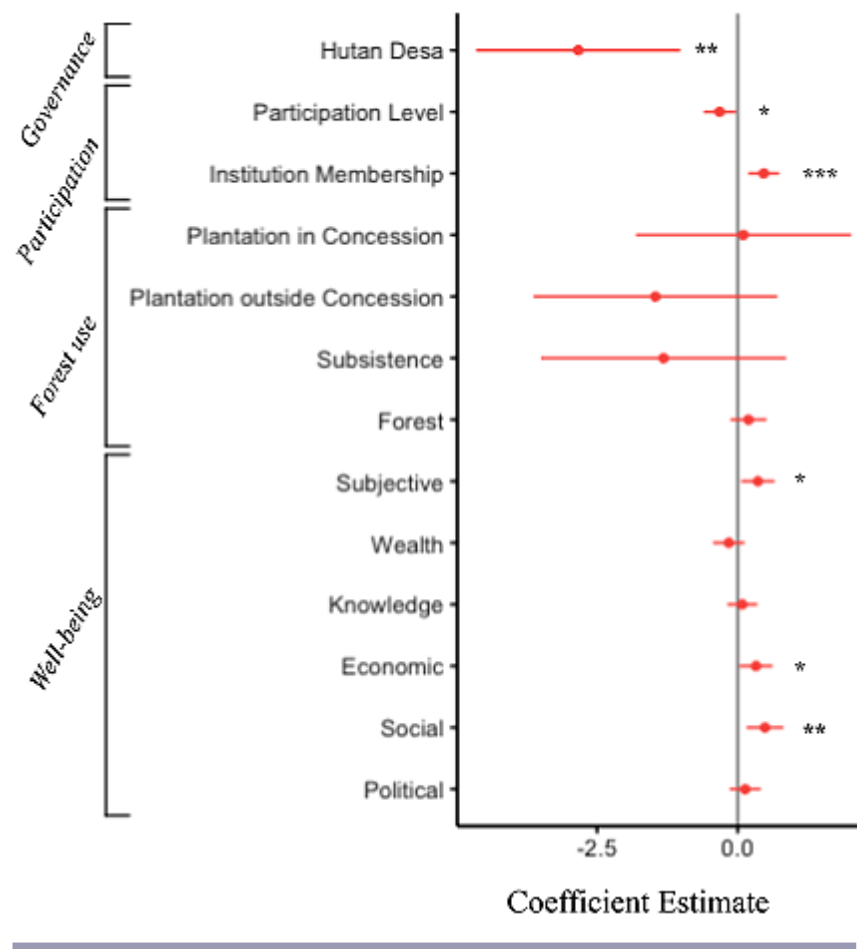

Alternatives: factors associated with forest use and awareness of Hutan Desa

Hutan Desa had a significant positive association with forest use (Table 4). Households in villages in which the dominant livelihoods were plantations outside of concessions and subsistence-based livelihoods were also positively associated with forest use. Greater participation in village meetings, procedural

Fig. 6. Coefficient estimates from cumulative link mixed model with conservation support level as the response variable.

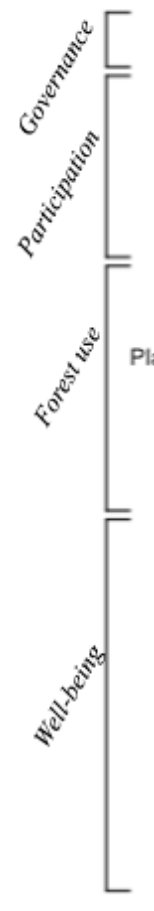

satisfaction, and membership in a village institution were all positively associated with household knowledge of whether their village had a Hutan Desa (Table 4). Forest use and plantation outside of concessions also demonstrated positive associations with awareness of the Hutan Desa. 
Table 4. Empirical results from generalized linear mixed models of forest use and awareness of Hutan Desa permitting status. Note that the reference level for dominant livelihood is other sectors.

\begin{tabular}{lccc}
\hline \hline Explanatory Variable & \multicolumn{2}{c}{ Forest Use } & Awareness of Hutan Desa \\
\hline & Coefficient & Std. error & Coefficient \\
Hutan Desa & $2.25^{*}$ & 0.91 & $2.45^{*}$ \\
Participation Level & 0.017 & 0.12 & $0.55^{* * *}$ \\
Institution Membership & 0.20 & 0.13 & $0.55^{* * *}$ \\
Procedural Satisfaction & $0.58^{*}$ & 0.23 & $0.79^{* *}$ \\
Dominant Livelihood: & & & 0.11 \\
Plantation in Concession & 1.39 & 0.96 & 1.69 \\
Plantation outside Concession & $2.55^{*}$ & 1.09 & $3.45^{*}$ \\
Subsistence & $3.04^{* *}$ & 1.07 & 2.09 \\
Forest Use & $\mathrm{NA}$ & $\mathrm{NA}$ & 0.12 \\
\hline
\end{tabular}

$p$ values $*<0.05 * *<0.01 * * *<0.001 ;$ NA not included in the model.

Fig. 7. (a) Average change in level of support for conservation in villages with a Hutan Desa between 2012 and 2017. (b) Level of support for forest conservation in 2017 for villages with and without Hutan Desa.

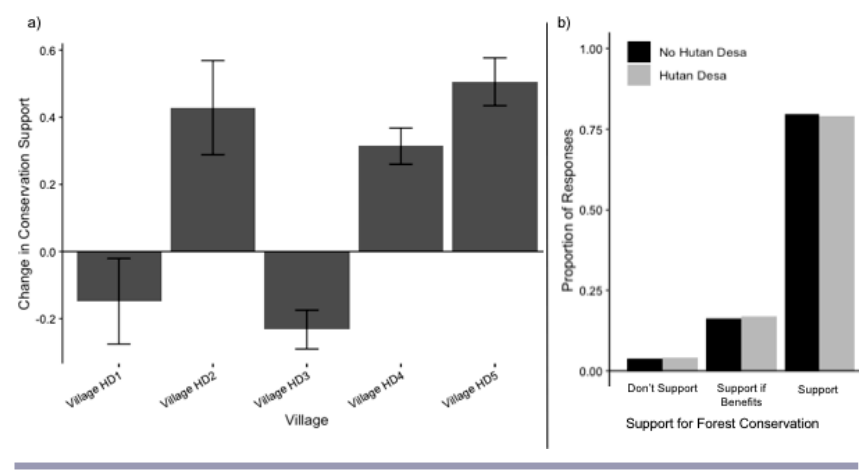

\section{DISCUSSION}

This study aimed to deepen our understanding of the connections between community-based forest management, participation in local decision making, and support for forest conservation. It sequentially examined elements of our conceptual model (Fig. 1) through the examination of a case study of the Hutan Desa model of CFM being implemented in Indonesian villages. The results suggest that Hutan Desa alone may not stimulate broad local participation, and that higher well-being is an important factor associated with level of participation. Furthermore, this study presented evidence that support for conservation objectives and active participation in local decision-making processes are related. This should not be taken as evidence to disregard the value of community-based forest management, rather that the governance instrument for CFM should be carefully sculpted to account for the existing social, economic, and institutional characteristics within a community. Together these findings pose a challenge for community-based forest management programs that seek to simultaneously achieve procedural equity and biodiversity conservation objectives.

\section{Underlying context is an important factor for participation in decision making}

Participation in village-level decision-making processes appears to be more positively associated with characteristics of respondent households (specifically well-being) rather than the presence of a Hutan Desa. Households with higher social standing and levels of well-being tend to participate in village decision-making processes to a greater extent in management of community natural resources (Corbera et al. 2007, Larson and Soto 2008, Tole 2010, Inoue et al. 2015). As other studies have highlighted, such instances of involvement by social elites have the potential to either hinder equitable participation or yield positive social and environmental outcomes, if the engaged elites prioritize the community's interests (e.g., Duguma et al. 2018 , Piabuo et al. 2018).

Who participates in decision making could have implications for the social outcomes of community forest programs. For instance, previous studies have critiqued the assumption of village cohesion under decentralized forest policies, depicting how asymmetric power dynamics can lead to unequal access to or benefits from community forests (Adhikari et al. 2004). Such unequal access is commonly attributed to instances in which a small influential or socially advantaged subset of a community dominates decision making on forest management (Agrawal and Gupta 2005, Subedi and Timilsina 2016), or in which certain marginal groups (e.g., based on gender, caste, income) are excluded from those processes (Lachapelle et al. 2004, Persson and Prowse 2017, Chaudhary et al. 2018). In this respect, one of the design features of Hutan Desa serves as a possible barrier to participation. By insisting that Hutan Desa villages build on existing institutional arrangements, the establishment and ongoing management of Hutan Desa may help perpetuate existing inequities in community leadership. Institutional arrangements that do not specifically seek to address underlying social inequities or engage vulnerable populations, have been shown to maintain whatever power dynamics are in place (Parker and Thapa 2011, Rasul et al. 2011, Sapkota et al. 2018). Additional data on communal governance, e.g., rules guiding who can participate, how decisions are taken, and how frequently meetings occur would enhance our understanding of the constraints and opportunities for participation within each village.

By comparing villages with and without Hutan Desa permits, our analysis indicates that simply adopting a community-based forest management scheme was not sufficient to overcome existing social inequities affecting participation levels. That CFM programs can overcome ingrained social inequities may in fact be an unreasonable expectation, and thus this lack of significant 
association should not be surprising. Particularly during the application process to obtain a Hutan Desa permit, the time and energy investments required to coordinate with external organizations and carry out the administrative processes may not align well with the high transaction costs associated with collective action, overhauling existing institutions, and engaging households with lower well-being levels (e.g., Marshall 2013). If increased or representative participation, or equal access to decision making is indeed a priority objective of CFM programs, complementary support for organizational capacity building and inclusive institutions may be necessary, in addition to the formal permitting process.

Finally, the relationships between dominant livelihoods and participation show the importance of different village settings. Villages dominated by plantations in oil palm concessions may have individuals who have benefited from this industry and are therefore more able to devote time to participation or becoming a member of village institutions. The positive association between active participation and subsistence-based livelihoods could reflect the nature of those communities and their approaches to communal decision making that some of the dominant indigenous groups practice (e.g., longhouse collective decision-making processes in Iban Dayak and Dayak Tamambaloh in Kapuas Hulu; Clerc 2012, Haryanti et al. 2015). These findings may also be relevant to other Indonesian islands, based on their specific livelihood contexts (e.g., Maluku has primarily subsistence-based communities).

\section{Linking community forest management with procedural equity}

If we consider procedural equity a product of inclusive decision making and satisfaction with the process, it appears there is room to improve both the representativeness of participation and procedural satisfaction. Although households with members of village institutions and greater social, subjective, and economic well-being demonstrated higher procedural satisfaction, a negative association was evident between Hutan Desa and satisfaction with forest-related decision making. Although not definitive across all community forest cases, these patterns suggest there is not always a procedural equity benefit to Hutan Desa. Not addressing these procedural inequities could lead to dissatisfaction with a program's objectives or impacts, subsequently reducing support for and compliance with forest management decisions (De Royer and Juita 2016).

However, equity may not be a primary objective of villages engaging in community-based forest management. For instance, De Royer, et al. (2018) similarly observed limited participation in their Indonesian case study. However, they argued that the policy was being implemented more as a means to resolve conflicts over tenure or justify forest occupation, rather than a tool to promote empowerment and social equity more broadly. In these cases, there may be a mismatch between governmental policy objectives and local motivations. As such, it is crucial to consider the range of community priorities when determining the forest governance instrument to be used.

\section{Participation and support for forest conservation}

Our investigation depicts a positive relationship between membership in the village institution and conservation support. As such, if the individuals most involved in making village decisions are more inclined toward conservation, then representative community participation in forest use and management may not be necessary (or even desirable) to achieve forest conservation outcomes. This study showed only a small subset of each village using forests regularly and engaging in village decision making. Particularly in cases in which the forests are not owned by individuals (most of Indonesia's forestry estate remains under state ownership), forest resources are often used at village level (or sometimes across villages; Clerc 2012). Therefore, intentions of individual actors may be less important than accounting for the inclinations of community leadership and how decisions are made.

Relationships between participation, forest use, and conservation support are likely not unidirectional. For instance, individuals who support conservation may be more inclined to participate in decision-making processes and have higher expectations for what qualifies as meaningful participation. Previous studies that have implied factors such as proximity to forests and the benefits households obtain from forest resources can also influence level of participation in CFM programs (e.g., Maskey et al. 2006, Gelo et al. 2016). Because participation would enable individuals to shape management programs to improve their use of forest resources, it stands to reason that those with a vested interest in forests would be inclined to participate.

It is also worth noting that the negative relationship between Hutan Desa and forest conservation support may be because of the expectation by community members that they will be able to benefit from the forest (and not set it aside purely for conservation). Improving communication around the existence of a Hutan Desa and potential benefits to village well-being (e.g., maintaining healthy ecosystems), could have positive impacts on expanding participation or indirectly influencing conservation support. Information about the Hutan Desa is often conveyed by word-ofmouth and at village meetings (De Royer and Juita 2016, De Royer et al. 2018). However, if residents do not regularly interact with social elites or attend village meetings, they may have no mechanism to obtain information about the village's forest-related activities. Overcoming this communication barrier could be an important foundation for increasing awareness and encouraging participation.

\section{Caveats and future research}

We explored relationships between participation, procedural satisfaction, and forest conservation support in the context of one CFM model. It is well-established that CFM is not a homogenous governance form, varying by how much individual cases decentralize decision making and the types of rights or benefits they support (Agrawal and Ostrom 2001, Persha et al. 2011). Because the particular type of institutional arrangement in this study builds upon an existing village decision-making body, it would be informative to compare the Hutan Desa model to others employed in Indonesia, e.g., Hutan Kemasyarakatan, Hutan Tanaman Rakyat, and Hutan Adat (Siscawati et al. 2017, Fisher et al. 2018). Each type has different aims and governance structures, which may diverge in terms of implications for participation or be more compatible with different community contexts. Such analyses would also be valuable in distinguishing variations under the diverse ethnic contexts across the Indonesian archipelago and to demonstrate where the findings from Hutan Desa in West Kalimantan are applicable across cases and where they are potentially case specific. 
Opportunities for further investigation also include the nature of participation itself and metrics of fair decision-making procedures. For instance, more complete time-series data could illustrate how procedural satisfaction changes over time, and indicate whether there are shifting expectations that arise with new institutions and greater participation. Furthermore, additional research could examine how the local perceptions align with local people's expectations of CFM. Although the stated objectives of the Hutan Desa program in Indonesia highlight conservation, well-being, and social equity, communities themselves may see the benefits in other terms, such as establishing a claim to or rights over forest resources. Thus, appropriate social metrics may not relate to equitability of procedure, but rather protection of forests from outside interests and perceptions around tenure security. These research questions would benefit from a different methodological approach (e.g., interviews or focus groups).

Lastly, to test the impacts of community forest management using household questionnaire data, we should use a matched beforeafter-control-intervention survey design when possible (Bowler et al. 2010, Sheppard et al. 2010). Such a design would help tease apart the issues of directionality, which the methods and data available for this study were unable to do. It would also help avoid some of the challenges associated with matching intervention villages with appropriate control sites and accounting for confounding site-level variables. However, in many cases with conservation projects (this study included), such complete data are not available.

\section{CONCLUSION}

Our case study identified characteristics within communities related to participation, procedural satisfaction, forest use, and conservation support. Importantly, we demonstrated how social and economic well-being are positively linked to participation in local decision-making processes, and how participation positively relates to procedural satisfaction and support for forest conservation. Although our study suggests that broad-scale participation in local decision making may not be a product of a Hutan Desa program, it does suggest the choice of institution and underlying social and economic context should be key considerations to achieve the stated objective of social equity. Governments can provide formalized rules in CFM programs to help address some of these more systemic social inequities (Chomba et al. 2015). At the same time, the study highlights the significant relationships between participation and conservation support, noting that improved communication of the benefits forests provide to communities may help strengthen both these factors.

Responses to this article can be read online at: http://www.ecologyandsociety.org/issues/responses. $\mathrm{php} / 11710$

\section{Acknowledgments:}

This study was conducted as part of the Monitoring and Evaluation of Social Forestry (Monitoring dan Evaluasi Perhutanan Sosial;
MEPS) program, supported by the UK Darwin Initiative [grant number 23-033], the Woodspring Trust, the Australian Research Council ( ARC) Centre of Excellence for Environmental Decisions [grant number CE11001000104], ARC Future Fellowship and Discovery programs, and the Arcus Foundation. The authors thank the people in the regencies of Kapuas Hulu and Ketapang for their generous help with and participation in the household surveys.

\section{Data Availability Statement:}

The data used in this study is openly available on the Open Science Framework at https://doi.org/10.17605/OSF.IO/KN5M3. Ethical approval for this research study was granted by University of Kent (reference number 011-ST-16).

\section{LITERATURE CITED}

Adger, W. N., K. Brown, and E. L. Tompkins. 2006. The political economy of cross-scale networks in resource co-management. Ecology and Society 10(2):9. https://doi.org/10.5751/ES-01465-100209

Adhikari, B., S. Di Falco, and J. C. Lovett. 2004. Household characteristics and forest dependency: evidence from common property forest management in Nepal. Ecological Economics 48 (2):245-257. https://doi.org/10.1016/i.ecolecon.2003.08.008

Agrawal, A. 2001. Common property institutions and sustainable governance of resources. World Development 29(10):1649-1672. https://doi.org/10.1016/S0305-750X(01)00063-8

Agrawal, A., A. Chhatre, and R. Hardin. 2008. Changing governance of the world's forests. Science 320(5882):1460-1462. https://doi.org/10.1126/science.1155369

Agrawal, A., and K. Gupta. 2005. Decentralization and participation: the governance of common pool resources in Nepal's Terai. World Development 33(7):1101-1114. https://doi. org/10.1016/j.worlddev.2005.04.009

Agrawal, A., and E. Ostrom. 2001. Collective action, property rights, and decentralization in resource use in India and Nepal. Politics and Society 29(4):485-514. https://doi.org/10.1177/0032$\underline{329201029004002}$

Ardiansyah, F., A. A. Marthen, and N. Amalia. 2015. Forest and land-use governance in a decentralized Indonesia: a legal and policy review. Occasional paper. Center for International Forestry Research, Bogor, Indonesia. [online] URL: https://www.cifor.org/ publications/pdf files/OccPapers/OP-132.pdf

Austin, K. G., M. González-Roglich, D. Schaffer-Smith, A. M. Schwantes, and J. J. Swenson. 2017. Erratum: trends in size of tropical deforestation events signal increasing dominance of industrial-scale drivers. Environmental Research Letters 12 (7):079601. https://doi.org/10.1088/1748-9326/aa7760

Austin, K. G., A. Schwantes, Y. Gu, and P. S. Kasibhatla. 2019. What causes deforestation in Indonesia? Environmental Research Letters 14(2):024007. https://doi.org/10.1088/1748-9326/aaf6db

Baker, S., and F. S. Chapin, III. 2018. Going beyond "it depends:" the role of context in shaping participation in natural resource management. Ecology and Society 23(1):20. https://doi. org/10.5751/es-09868-230120 
Baynes, J., J. Herbohn, C. Smith, R. Fisher, and D. Bray. 2015. Key factors which influence the success of community forestry in developing countries. Global Environmental Change 35:226-238. https://doi.org/10.1016/j.gloenvcha.2015.09.011

Bojanowski, M., and R. Edwards. 2016. alluvial: R package for creating alluvial diagrams. $\mathrm{R}$ package version: $0.1-2$. $\mathrm{R}$ Foundation, Vienna, Austria. [online] URL: https://github.com/ mbojan/alluvial

Bowler, D., L. Buyung-Ali, J. R. Healey, J. P. G. Jones, T. Knight, and A. S. Pullin. 2010. The evidence base for community forest management as a mechanism for supplying global environmental benefits and improving local welfare. Centre for Evidence-Based Conservation, SENRGY, Bangor University, Bangor, UK. [online] URL: https://www.thegef.org/sites/default/files/publications/ STAP_CFM_2010_1.pdf

Brockhaus, M., K. Obidzinski, A. Dermawan, Y. Laumonier, and C. Luttrell. 2012. An overview of forest and land allocation policies in Indonesia: is the current framework sufficient to meet the needs of REDD+? Forest Policy and Economics 18:30-37. https://doi.org/10.1016/j.forpol.2011.09.004

Cahyat, A., C. Gönner, and M. Haug. 2007. Assessing household poverty and wellbeing: a manual with examples from Kutai Barat, Indonesia. Center for International Forestry Research, Bogor, Indonesia. https://doi.org/10.17528/cifor/002265

Charnley, S., and M. R. Poe. 2007. Community forestry in theory and practice: where are we now? Annual Review of Anthropology 36(1):301-336. https://doi.org/10.1146/annurev.anthro.35.081705.123143

Chaudhary, S., A. McGregor, D. Houston, and N. Chettri. 2018. Environmental justice and ecosystem services: a disaggregated analysis of community access to forest benefits in Nepal. Ecosystem Services 29:99-115. https://doi.org/10.1016/j.ecoser.2017.10.020

Chhetri, B. B. K., F. H. Johnsen, M. Konoshima, and A. Yoshimoto. 2013. Community forestry in the hills of Nepal: determinants of user participation in forest management. Forest Policy and Economics 30:6-13. https://doi.org/10.1016/j. forpol.2013.01.010

Chomba, S. W., I. Nathan, P. A. Minang, and F. Sinclair. 2015. Illusions of empowerment? Questioning policy and practice of community forestry in Kenya. Ecology and Society 20(3):2. https://doi.org/10.5751/ES-07741-200302

Christensen, R. H. B. 2018. Ordinal:regression models for ordinal data. R Foundation, Vienna, Austria. [online] URL: https:// github.com/runehaubo/ordinal

Clerc, J. 2012. Unpacking tenure security: development of a conceptual framework and application to the case of oil palm expansion on customary land in Kapuas Hulu district, West Kalimantan, Indonesia. Center for International Forestry Research, Bogor, Indonesia. https://doi.org/10.17528/cifor/004012

Colchester, M. 2003. Bridging the gap: challenges to community forestry networking in Indonesia. Center for International Forestry Research, Bogor, Indonesia. [online] URL: http://www.cifor.org/ publications/pdf files/cf/indonesia cf.pdf

Corbera, E., N. Kosoy, and M. M. Tuna. 2007. Equity implications of marketing ecosystem services in protected areas and rural communities: case studies from Meso-America. Global Environmental Change 17(3-4):365-380. https://doi.org/10.1016/j. gloenvcha.2006.12.005

De Royer, S., and R. Juita. 2016. Village forest licences (Hutan Desa) in West Kalimantan: way forward for equity and land security? World Agroforestry Centre, Bogor, Indonesia. [online] URL: http://outputs.worldagroforestry.org/cgi-bin/koha/opacdetail.pl?biblionumber $=39715$

De Royer, S., M. Van Noordwijk, and J. M. Roshetko. 2018. Does community-based forest management in Indonesia devolve social justice or social costs? International Forestry Review 20 (2):167-180. https://doi.org/10.1505/146554818823767609

Duguma, L. A., J. Atela, A. N. Ayana, D. Alemagi, M. Mpanda, M. Nyago, P. A. Minang, J. M. Nzyoka, D. Foundjem-Tita, and C. N. Ntamag-Ndjebet. 2018. Community forestry frameworks in sub-Saharan Africa and the impact on sustainable development. Ecology and Society 23(4):21. https://doi. org/10.5751/ES-10514-230421

Fisher, L. A., Y.-S. Kim, S. Latifah, and M. Mukarom. 2017. Managing forest conflicts: perspectives of Indonesia's forest management unit directors. Forest and Society 1(1):8. https://doi. org/10.24259/fs.v1i1.772

Fisher, M. R., M. Moeliono, A. Mulyana, E. L. Yuliani, A. Adriadi, Kamaluddin, J. Judda, and M. A. K. Sahide. 2018. Assessing the new social forestry project in Indonesia: recognition, livelihood and conservation? International Forestry Review 20(3):346-361. https://doi.org/10.1505/146554818824063014

Fisher, R. J. 1999. Decentralization and devolution of forest management in Asia and the Pacific. FAO Working Paper Series. Food and Agriculture Organization of the United Nations, Rome, Italy. [online] URL: http://www.fao.org/3/x3030e/x3030e03.htm

Food and Agriculture Organization of the United Nations (FAO). 2011. Reforming forest tenure: issues, principles and process. FAO Forestry Paper 165. Food and Agriculture Organization of the United Nations, Rome, Italy. [online] URL: http://www.fao.org/ policy-support/tools-and-publications/resources-details/en/c/1235249/

Friedman, R. S., E. A. Law, N. J. Bennett, C. D. Ives, J. P. R. Thorn, and K. A. Wilson. 2018. How just and just how? A systematic review of social equity in conservation research. Environmental Research Letters 13(5). https://doi.org/10.1088/1748-9326/ $\underline{\text { aabcde }}$

Gaveau, D. L. A., D. Sheil, Husnayaen, M. A. Salim, S. Arjasakusuma, M. Ancrenaz, P. Pacheco, and E. Meijaard. 2016. Rapid conversions and avoided deforestation: examining four decades of industrial plantation expansion in Borneo. Scientific Reports 6(September):32017. https://doi.org/10.1038/srep32017

Gelo, D., E. Muchapondwa, and S. F. Koch. 2016. Decentralization, market integration and efficiency-equity tradeoffs: evidence from joint forest management in Ethiopian villages. Journal of Forest Economics 22:1-23. https://doi.org/10.1016/j. jfe.2015.10.003

Gelman, A., and J. Hill. 2007. Data analysis using regression and multilevel/hierarchical models. Cambridge University Press, Cambridge, UK. 
Gilmour, D. 2016. Forty years of community-based forestry: a review of its extent and effectiveness. Food and Agriculture Organization of the United Nations, Rome, Italy. [online] URL: https://www.cbd.int/financial/doc/fao-communityforestry2016.pdf

Gönner, C., M. Haug, A. Cahyat, E. Wollenberg, W. de Jong, G. Limberg, P. Cronkleton, M. Moeliono, and M. Becker. 2007. Capturing nested spheres of poverty a model for multidimensional poverty analysis and monitoring. CIFOR Occasional Paper No 46. Center for International Forestry Research, Bogor, Indonesia. https://doi.org/10.17528/cifor/002255

Gurney, G. G., J. E. Cinner, J. Sartin, R. L. Pressey, N. C. Ban, N. A. Marshall, and D. Prabuning. 2016. Participation in devolved commons management: multiscale socioeconomic factors related to individuals' participation in community-based management of marine protected areas in Indonesia. Environmental Science and Policy 61:212-220. https://doi.org/10.1016/j.envsci.2016.04.015

Gustavsson, M., L. Lindström, N. S. Jiddawi, and M. de la TorreCastro. 2014. Procedural and distributive justice in a communitybased managed marine protected area in Zanzibar, Tanzania. Marine Policy 46:91-100. https://doi.org/10.1016/j.marpol.2014.01.005

Haryanti, E. S., F. Diba, and Wahdina. 2015. Etnobotani tumbuhan berguna oleh masyarakat sekitar kawasan $\mathrm{kph}$ model kapus hulu. Jurnal Hutan Lestari 3(3). [online] URL: http:// jurnal.untan.ac.id/index.php/jmfkh/article/view/11370/10778

Inoue, M., G. P. Shivakoti, and H. R. Ojha. 2015. Multi-level forest governance in Asia: an introduction. Pages 3-18 in M. Inoue and G. P. Shivakoti, editors. Multi-level forest governance in Asia: concepts, challenges and the way forward. Sage, Thousand Oaks, California, USA.

Jewitt, S. L., D. Nasir, S. E. Page, J. O. Rieley, and K. Khanal. 2014. Indonesia's contested domains. Deforestation, rehabilitation and conservation-with-development in Central Kalimantan's tropical peatlands. International Forestry Review 16(4):405-420. https://doi.org/10.1505/146554814813484086

Kassambara, A. 2018. ggcorrplot: visualisation of a correlation matrix using 'ggplot2.'. R Package. R Foundation, Vienna, Austria. [online] URL: https://cran.r-project.org/web/packages/ ggcorrplot/ggcorrplot.pdf

Kellert, S. R., J. N. Mehta, S. A. Ebbin, and L. L. Lichtenfield. 2000. Community natural resource management: promise, rhetoric, and reality. Society and Natural Resources 13(8):705-715. https://doi.org/10.1080/089419200750035575

Kuznetsova, A., P. B. Brockhoff, and R. H. B. Christensen. 2017. lmerTest package: tests in linear mixed effects models. Journal of Statistical Software 82(13):1-26. https://doi.org/10.18637/jss. $\underline{\mathrm{v} 082.113}$

Lachapelle, P. R., P. D. Smith, and S. F. Mccool. 2004. Access to power or genuine empowerment? An analysis of three community forest groups in Nepal. Human Ecology Review 11(1):1-12. [online] URL: http://www.humanecologyreview.org/pastissues/ her111/111lachapellesmithmccool.pdf

Larson, A. M., and F. Soto. 2008. Decentralization of natural resource governance regimes. Annual Review of Environmental Resources 33:213-239. https://doi.org/10.1146/annurev. environ.33.020607.095522
Law, E. A., N. J. Bennett, C. D. Ives, R. Friedman, K. J. Davis, C. Archibald, and K. A. Wilson. 2018. Equity trade-offs in conservation decision making. Conservation Biology 32 (2):294-303. https://doi.org/10.1111/cobi.13008

Marshall, G. R. 2013. Transaction costs, collective action and adaptation in managing complex social-ecological systems. Ecological Economics 88:185-194. https://doi.org/10.1016/j. ecolecon.2012.12.030

Martin, A., N. Gross-camp, B. Kebede, and S. Mcguire. 2014. Measuring effectiveness, efficiency and equity in an experimental payments for ecosystem services trial. Global Environmental Change 28:216-226. https://doi.org/10.1016/j.gloenvcha.2014.07.003

Maskey, V., T. G. Gebremedhin, and T. J. Dalton. 2006. Social and cultural determinants of collective management of community forest in Nepal. Journal of Forest Economics 11 (4):261-274. https://doi.org/10.1016/j.jfe.2005.10.004

McDermott, M., S. Mahanty, and K. Schreckenberg. 2013. Examining equity: a multidimensional framework for assessing equity in payments for ecosystem services. Environmental Science and Policy 33:416-427. https://doi.org/10.1016/j.envsci.2012.10.006

Ministry of Environment and Forestry Indonesia (MEF). 2016. Peraturan menteri lingkungan hidup dan kehutanan republik Indonesia nomor 83/MENLHK/SETJEN/KUM.1/2016 Tentang Perhutanan Sosial. Ministry of Environment and Forestry Indonesia, Jakarta, Indonesia.

Negi, S., T. T. Pham, B. Karky, and C. Garcia. 2018. Role of community and user attributes in collective action: case study of community-based forest management in Nepal. Forests 9(3):136. https://doi.org/10.3390/f9030136

Ostrom, E. 1990. Governing the commons: the evolution of institutions for collective action. Cambridge University Press, Cambridge, UK.

Pagdee, A., Y.-S. Kim, and P. J. Daugherty. 2006. What makes community forest management successful: a meta-study from community forests throughout the world. Society and Natural Resources 19(1):33-52. https://doi.org/10.1080/08941920500323260

Parker, P., and B. Thapa. 2011. Distribution of benefits based on household participation roles in decentralized conservation within Kanchenjunga Conservation Area Project, Nepal. Environment, Development and Sustainability 13(5):879-899. https://doi.org/10.1007/s10668-011-9296-6

Persha, L., Agrawal, A., and A. Chhatre. 2011. Social and ecological synergy: local rulemaking. Forest Livelihoods, and Biodiversity Conservation Science 331(6024):1606-1608. https:// doi.org/10.1126/science.1199343

Persha, L., and K. Andersson. 2014. Elite capture risk and mitigation in decentralized forest governance regimes. Global Environmental Change - Human and Policy Dimensions 24:265-276. https://doi.org/10.1016/j.gloenvcha.2013.12.005

Persson, J., and M. Prowse. 2017. Forest policy and economics collective action on forest governance: an institutional analysis of the Cambodian community forest system. Forest Policy and Economics 83:70-79. https://doi.org/10.1016/j.forpol.2017.06.008 
Piabuo, S. M., D. Foundjem-Tita, and P. A. Minang. 2018. Research, part of a special feature on twenty years of community forestry in Cameroon: opportunities and challenges for sustainable development community forest governance in Cameroon: a review. Ecology and Society 23(3):34. https://doi. org/10.5751/es-10330-230334

Presiden Republic of Indonesia (RI). 2014. Peraturan Presiden Republik Indonesia Nomor 2 Tahun 2015 Tentang Rencana Pembangunan Jangka Menengah Nasional RPJMN 2015-2019: Indonesia yang Berdaulat, Mandiri dan Berkepribadian Berlandaskan Gotong Royong. Buku 1 Agenda Pembangunan Nasional. Kementerian Perencanaan Pembangunan Nasional/ Badan Perencanaan Pembangunan Nasional, Jakarta, Indonesia.

Raik, D. B., A. L. Wilson, and D. J. Decker. 2008. Power in natural resources management: an application of theory. Society and Natural Resources 21(8):729-739. https://doi.org/10.1080/08941$\underline{920801905195}$

R Core Team. 2018. R: a language and environment for statistical computing. R Foundation for Statistical Computing, Vienna, Austria. [online] URL: https://www.r-project.org/

Rasul, G., G. B. Thapa, and M. B. Karki. 2011. Comparative analysis of evolution of participatory forest management institutions in South Asia. Society and Natural Resources 24 (12):1322-1334. https://doi.org/10.1080/08941920.2010.545966

Reed, M. S. 2008. Stakeholder participation for environmental management: a literature review. Biological Conservation 141 (10):2417-2431. https://doi.org/10.1016/j.biocon.2008.07.014

Royo, N., and A. Wells. 2012. Community based forest management in Indonesia: a review of current practice and regulatory frameworks. The Forest Dialogue, New Haven, Connecticut, USA. [online] URL: https://theforestsdialogue.org/ $\underline{\text { sites/default/files/ilcf indonesia background paper english.pdf }}$

Sahide, M. A. K., S. Supratman, A. Maryudi, Y.-S. Kim, and L. Giessen. 2016. Decentralisation policy as recentralisation strategy: forest management units and community forestry in Indonesia. International Forestry Review 18(1):78-95. https://doi. org/10.1505/146554816818206168

Saito-Jensen, M., I. Nathan, and T. Treue. 2010. Beyond elite capture? Community-based natural resource management and power in Mohammed Nagar village, Andhra Pradesh, India. Environmental Conservation 37(3):327-335. https://doi.org/10.1017/ $\underline{\mathrm{S} 0376892910000664}$

Santika, T., E. Meijaard, S. Budiharta, E. A. Law, A. Kusworo, J. A. Hutabarat, T. P. Indrawan, M. Struebig, S. Raharjo, I. Huda, Sulhani, A. D. Ekaputri, S. Trison, M. Stigner, and K. A. Wilson. 2017. Community forest management in Indonesia: avoided deforestation in the context of anthropogenic and climate complexities. Global Environmental Change 46:60-71. https://doi. org/10.1016/j.gloenvcha.2017.08.002

Santika, T., K. A. Wilson, S. Budiharta, A. Kusworo, E. Meijaard, E. A. Law, R. Friedman, J. A. Hutabarat, T. P. Indrawan, F. A. V. St. John, and M. J. Struebig. 2019. Heterogeneous impacts of community forestry on forest conservation and poverty alleviation: evidence from Indonesia. People and Nature 1 (2):204-219. https://doi.org/10.1002/pan3.25
Sapkota, P., R. J. Keenan, and H. R. Ojha. 2018. Community institutions, social marginalization and the adaptive capacity: a case study of a community forestry user group in the Nepal Himalayas. Forest Policy and Economics 92:55-64. https://doi. org/10.1016/j.forpol.2018.04.001

Schreckenberg, K., C. Luttrell, and C. Moss. 2006. Forest policy and environment programme: grey literature participatory forest management: an overview. Overseas Development Institute, London, UK.

Sheppard, D. J., A. Moehrenschlager, J. M. Mcpherson, and J. J. Mason. 2010. Ten years of adaptive community-governed conservation: evaluating biodiversity protection and poverty alleviation in a West African hippopotamus reserve. Environmental Conservation 37(3):270-282. https://doi.org/10.1017/ S037689291000041X

Siscawati, M., M. R. Banjade, N. Liswanti, T. Herawati, E. Mwangi, C. Wulandari, M. Tjoa, and T. Silaya. 2017. Overview of forest tenure reforms in Indonesia. Working Paper 223. Center for International Forestry Research, Bogor, Indonesia. [online] URL: https://www.cifor.org/publications/pdf files/WPapers/ WP223Siscawati.pdf

Smith, P. D., and M. H. McDonough. 2001. Beyond public participation: fairness in natural resource decision making. Society and Natural Resources 14(3):239-249. https://doi. org/10.1080/089419201750111056

Subedi, M. R., and Y. P. Timilsina. 2016. Evidence of user participation in community forest management in the mid-hills of Nepal: a case of rule making and implementation. Small-scale Forestry 15(2):257-270. https://doi.org/10.1007/s11842-015-9321$\mathrm{y}$

Tole, L. 2010. Reforms from the ground up: a review of community-based forest management in tropical developing countries. Environmental Management 45(6):1312-1331. https:// doi.org/10.1007/s00267-010-9489-Z

van Noordwijk, M. 2019. Integrated natural resource management as pathway to poverty reduction: innovating practices, institutions and policies. Agricultural Systems 172:60-71. https://doi.org/10.1016/j.agsy.2017.10.008

Vimal, R., M. Khalil-Lortie, and T. Gatiso. 2018. What does community participation in nature protection mean? The case of tropical national parks in Africa. Environmental Conservation 45 (4):324-332. https://doi.org/10.1017/S0376892917000583

Ward, C., L. C. Stringer, and G. Holmes. 2018. Protected area comanagement and perceived livelihood impacts. Journal of Environmental Management 228:1-12. https://doi.org/10.1016/j. jenvman.2018.09.018 
Appendix 1. Control villages for NESP survey 2017.

\section{Summary}

Table A1.1. List of control villages for each HD based on variables used in matching: (a) B1 (primary biophysical variables), (b) B1 \& B2 (both primary and secondary biophysical variables), (c) B1 \& P1 (primary biophysical and basic human wellbeing variables), (d) B1, B2 \& P1 (biophysical and basic human wellbeing variables), and (e) B1, B2, P1 \& P2 (biophysical, basic human wellbeing and infrastructure variables) (see Table 2 for baseline variables B1, B2, P1 \& P2). Cell highlighted in orange represents the eligible control based on matching variables for column (b)(e). Cell highlighted in red represents the most suitable control village (closest match to HD), and cell highlighted in blue represents the second most suitable control village. The final control was selected minimizing column (b) or (c).

\begin{tabular}{|c|c|c|c|c|c|c|c|}
\hline \multirow[b]{2}{*}{$\begin{array}{c}\text { Kab. } \\
\text { (District) }\end{array}$} & \multirow[b]{2}{*}{$\begin{array}{l}\text { Hutan Desa } \\
\text { (HD) }\end{array}$} & \multirow[b]{2}{*}{ Kecamatan } & \multirow{2}{*}{$\begin{array}{c}\text { Control village candidates, } \\
\text { based on } \$\end{array}$} & \multicolumn{4}{|c|}{$\begin{array}{c}\text { Similarity to HD } \\
\text { (smaller value indicates closer match) }\end{array}$} \\
\hline & & & & $\begin{array}{c}\text { (b) } \\
\text { B1 \& } \\
\text { B2 }\end{array}$ & $\begin{array}{c}\text { c) } \\
\text { B1 \& } \\
\text { P1 }\end{array}$ & $\begin{array}{c}(\mathrm{d}) \\
\mathrm{B} 1, \mathrm{~B} 2 \& \\
\mathrm{P} 1\end{array}$ & $\begin{array}{c}\text { (e) } \\
\mathrm{B} 1, \mathrm{~B} 2, \mathrm{P} 1 \\
\& \mathrm{P} 2\end{array}$ \\
\hline \multirow[t]{18}{*}{ Ketapang } & Laman & Sandai & Sandai (M, HPK) & 4.33 & 2.58 & 5.04 & 5.37 \\
\hline & \multirow{10}{*}{$\begin{array}{l}\text { Satong } \\
\text { (M, HPK) }\end{array}$} & Simpang Hulu & Balai Pinang (M,HPK) & 3.89 & 0.60 & 3.94 & 4.04 \\
\hline & & Nanga Tayap & Kayong Utara (M,HP) $\mathbf{X}$ & 3.26 & 0.04 & 3.26 & 3.83 \\
\hline & & Sandai & Merimbang Jaya $(\mathrm{M}, \mathrm{HP})$ & 3.54 & 1.95 & 4.04 & 6.94 \\
\hline & & Simpang Dua & Semandang Kanan (M,HP) & 4.19 & 3.55 & 5.49 & 5.62 \\
\hline & & Simpang Hulu & Paoh Concong (M,HP) & 3.09 & 1.92 & 3.64 & 3.74 \\
\hline & & Simpang Hulu & Semandang Kiri (M,HP) & 3.10 & 2.01 & 3.70 & 3.86 \\
\hline & & Sungai Melayu Rayak & Sei Melayu (M,HP) & 4.76 & 3.72 & 6.05 & 6.41 \\
\hline & & Sungai Melayu Rayak & Suka Mulya (M,HP) & 6.19 & 2.06 & 6.52 & 6.59 \\
\hline & & Tumbang Titi & Mahawa (M,HP) & 2.26 & 3.50 & 4.16 & 4.77 \\
\hline & & Tumbang Titi & Nanga Kelampai (M,HP) & 5.03 & 3.27 & 6.00 & 6.49 \\
\hline & \multirow{7}{*}{\begin{tabular}{|l|} 
Pematang \\
Gadung \\
$(\mathrm{P}, \mathrm{HPK})$
\end{tabular}} & Manis Mata & Suka Ramai (P,HPK) & 2.81 & 1.97 & 3.44 & 3.64 \\
\hline & & Air Upas & Air Durian Jaya (P,HP) & 2.32 & 1.98 & 3.05 & 3.13 \\
\hline & & Kendawangan & Air Tarap (P,HP) & 3.07 & 2.69 & 4.08 & 6.40 \\
\hline & & Kendawangan & Suka Damai (P,HP) & 2.15 & 1.96 & 2.91 & 2.93 \\
\hline & & Nanga Tayap & Sungai Kelik (P,HP) $\mathbf{X}$ & 1.55 & 3.37 & 3.71 & 3.72 \\
\hline & & Simpang Hulu & Kualan Hilir (P,HP) & 4.59 & 3.84 & 5.99 & 6.73 \\
\hline & & Singkup & Pantai Ketikal (P,HP) & 2.16 & 2.61 & 3.39 & 3.58 \\
\hline \multirow{9}{*}{$\begin{array}{l}\text { Kapuas } \\
\text { Hulu }\end{array}$} & \multirow{5}{*}{\begin{tabular}{|l|} 
Мепиа \\
Sadap \\
(M, HPT)
\end{tabular}} & Badau & Badau (M,HPT) & 4.47 & 3.13 & 5.68 & 6.20 \\
\hline & & Boyan Tanjung & Boyan Tanjung (M,HPT) & 5.35 & 4.45 & 7.12 & 8.34 \\
\hline & & Hulu Gurung & Kelakar (M,HPT) X & 2.84 & 3.50 & 4.39 & 5.16 \\
\hline & & Hulu Gurung & Nanga Tepuai (M,HPT) & 4.41 & 3.92 & 5.99 & 6.48 \\
\hline & & Pengkadan & Riam Panjang (M,HPT) X & 2.63 & 3.13 & 4.00 & 4.38 \\
\hline & \multirow{4}{*}{$\begin{array}{l}\text { Nanga Lauk } \\
(\mathrm{P}, \mathrm{HL})\end{array}$} & Embaloh Hulu & Pulau Manak (P,HL) X & 2.99 & 1.05 & 3.46 & 4.84 \\
\hline & & Embaloh Hulu & Tamao (P,HL) & 2.59 & 3.22 & 4.01 & 4.59 \\
\hline & & Putussibau Utara & Nanga Awin $(\mathrm{P}, \mathrm{HL})$ & 3.55 & 1.17 & 4.09 & 5.74 \\
\hline & & Putussibau Utara & Nanga Nyabau $(\mathrm{P}, \mathrm{HL}) \mathbf{X}$ & 4.33 & 3.56 & 5.74 & 6.10 \\
\hline
\end{tabular}

$\$ \mathrm{HL}=$ Hutan Lindung (Watershed protection forest), HPT $=$ Hutan Produksi Teerbatas (Limited production forest), HP = Hutan Produksi Tetap (Permanent production forest), HPK = Hutan Produksi Konversi (Convertible production forest). $\mathrm{M}=$ Mineral soil, $\mathrm{P}=$ Peat soil. 
Table A1.2. List of baseline variables used in matching: (a) B1 (primary biophysical variables), (b) B2 (secondary biophysical variables), (c) P1 (basic human wellbeing variables), and (d) P2 (infrastructure variables).

\begin{tabular}{|c|c|c|c|}
\hline Aspect to match & Description & PODES + variable & Response \\
\hline \multirow{2}{*}{$\begin{array}{l}\text { Biophysical - } \\
\text { Primary }(\text { B1) }\end{array}$} & \multirow[t]{2}{*}{ Location } & Location on peat & Binary \\
\hline & & Forest functional zone & $\begin{array}{l}\text { Categorical (HL, HPT, } \\
\text { HP/HPK) }\end{array}$ \\
\hline \multirow{5}{*}{$\begin{array}{l}\text { Biophysical - } \\
\text { Secondary }(\mathrm{B} 2)\end{array}$} & \multirow{5}{*}{$\begin{array}{l}\text { Anthropogenic } \\
\text { pressure }\end{array}$} & Forest area & Continuous \\
\hline & & Forest loss (2005-2015) & Continuous \\
\hline & & Elevation & Continuous \\
\hline & & Slope & Continuous \\
\hline & & Distance to cities and major roads & Continuous \\
\hline \multirow{5}{*}{$\begin{array}{l}\text { Poverty -Basic } \\
\text { human wellbeing } \\
\text { (P1) }\end{array}$} & \multirow[t]{5}{*}{$\begin{array}{l}\text { Living } \\
\text { conditions }\end{array}$} & $\begin{array}{l}\text { Proportions of families living in poor } \\
\text { housing conditions or slums }\end{array}$ & Continuous \\
\hline & & Households with electricity & Continuous \\
\hline & & $\begin{array}{l}\text { Energy for cooking for the majority of } \\
\text { households }\end{array}$ & $\begin{array}{l}\text { Categorical }(1=\text { natural } \\
\text { gas/electricity, } 2=\text { kerosene, } \\
3=\text { others })\end{array}$ \\
\hline & & $\begin{array}{l}\text { Toilet facilities for the majority of } \\
\text { households }\end{array}$ & $\begin{array}{l}\text { Categorical ( } 1=\text { own toilet, } \\
2=\text { joint toilet, } 3=\text { public } \\
\text { toilet, } 4=\text { non-toilet })\end{array}$ \\
\hline & & $\begin{array}{l}\text { Children malnutrition incidence in the last } \\
\text { year }\end{array}$ & Continuous \\
\hline \multirow{4}{*}{$\begin{array}{l}\text { Poverty - } \\
\text { Infrastructure } \\
(\text { P2) }\end{array}$} & \multirow{4}{*}{$\begin{array}{l}\text { Access to health, } \\
\text { knowledge, } \\
\text { infrastructure and } \\
\text { services }\end{array}$} & Distance to the nearest health facility & Continuous \\
\hline & & Distance to nearest elementary school & Continuous \\
\hline & & Number of elementary schools nearby & Continuous \\
\hline & & Distance to nearest secondary school & Continuous \\
\hline
\end{tabular}

\$ PODES is the Pendataan Potensi Desa or Village Potential Statistics from the Bureau of Statistics/Badan Pusat Statistik of the Republic of Indonesia. This statistical matching used data from the 2014 survey, for which the report is available online, but the data is not open access

(https://www.bps.go.id/publication/2014/12/16/7107f6b0f1a6f3e4619a2e0e/statistik-potensi-desa-indonesia2014.html) 
Appendix 2. Supplemental information on methods, analyses, and results.

Survey responses

Table A2.1. Sample sizes and basic demographics for data collected in the study villages

\begin{tabular}{llcccccc}
\hline Regency & \multicolumn{1}{c}{ Village } & \multicolumn{2}{c}{ \# Respondents } & \multicolumn{2}{c}{ Gender } & \multicolumn{2}{c}{ Average } \\
& & 2012 & 2017 & Households & Male & Female & $\begin{array}{c}\text { Age } \\
(2017)\end{array}$ \\
& & & & & & & 49.17 \\
Kapuas & Village HD1 & 27 & 29 & 33.3 & 25 & 32 & 46.26 \\
& Village HD2 & 28 & 41 & 33.3 & 32 & 6 & 43.78 \\
& Village NHD1 & NA & 103 & 33.3 & 79 & 23 & 49.5 \\
& Village NHD2 & NA & 32 & 33.3 & 25 & 7 & 45.43 \\
& Village HD3 & 142 & 160 & 20 & 57 & 103 & 47.09 \\
& Village HD4 & 174 & 252 & 20 & 187 & 65 & 43.43 \\
& Village HD5 & 87 & 276 & 20 & 257 & 119 & 43.29 \\
& Village HD6 & NA & 213 & 20 & 199 & 14 & 46.33 \\
\hline
\end{tabular}

\section{Calculation of wellbeing scores}

The calculation of the score for wellbeing variables followed the guidelines of Cahyat (2007). The poverty spheres included Subjective Wellbeing (SWB), a Core of basic needs (material wealth and knowledge spheres), and Context (economic, social, and political spheres). Each of these spheres was composed of 2-4 variables, with integer values between 1 and 3. A score was calculated for each sphere for each individual by normalization (scaling) the variables to get a composite value between 0 and 1 . The values for the variables in each sphere were added together, and the sum of the minimum values subtracted ${ }^{1}$. This was divided by the difference between the sum of maximum values and minimum values.

To calculate thresholds, we followed the formula in Cahyat (2007), although one could determine these through stakeholder consultation processes or similar methods. For each variable, 100 is divided by the number of possible values, then these are summed and divided by the number of variables for each sphere ${ }^{2}$. Any values that fell below this threshold were then considered in a "critical" poverty condition. The threshold for determining a high level of wellbeing was calculated by subtracting the critical threshold from 100, and anything above this is considered to be in good condition.

\footnotetext{
${ }^{1}$ [(sum of individuals' scores - sum of min scores possible) / (sum of max scores possible - sum of min scores possible)]*100

2 [sum of [100 / number of possible values for variable]] / number of variables summed
} 


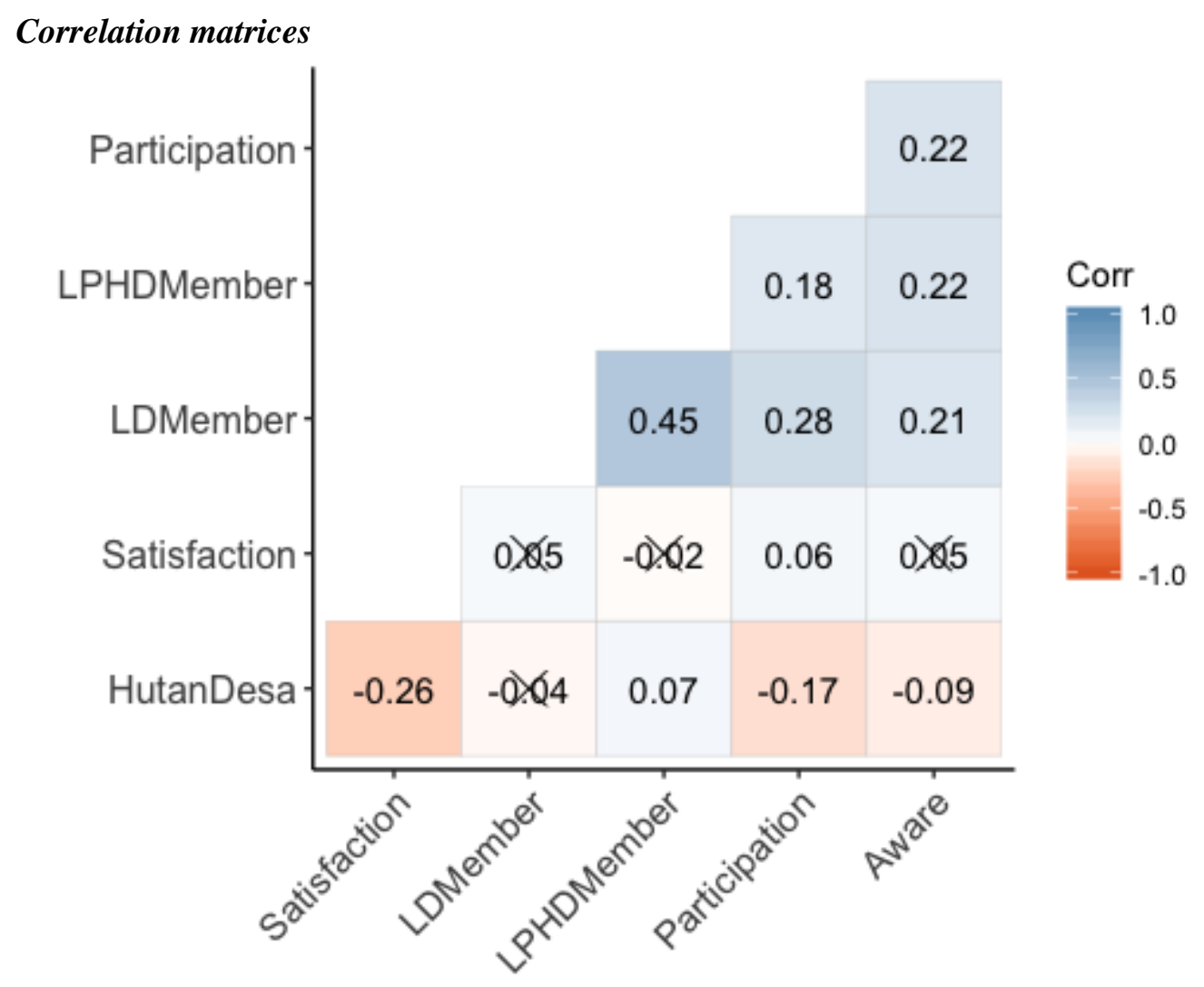

Figure A2.1. Correlation matrix to identify any existing relationships between Hutan Desa and participation variables. No strong correlations were identified. Of note, there is a positive correlation between member of any village institution (LD) and member of the Hutan Desa management committee (LPHD). We have excluded the LPHD variable from the analysis, because it is only relevant to those communities with Hutan Desa; however, it there clearly is overlap between memberships of the two institutions. 


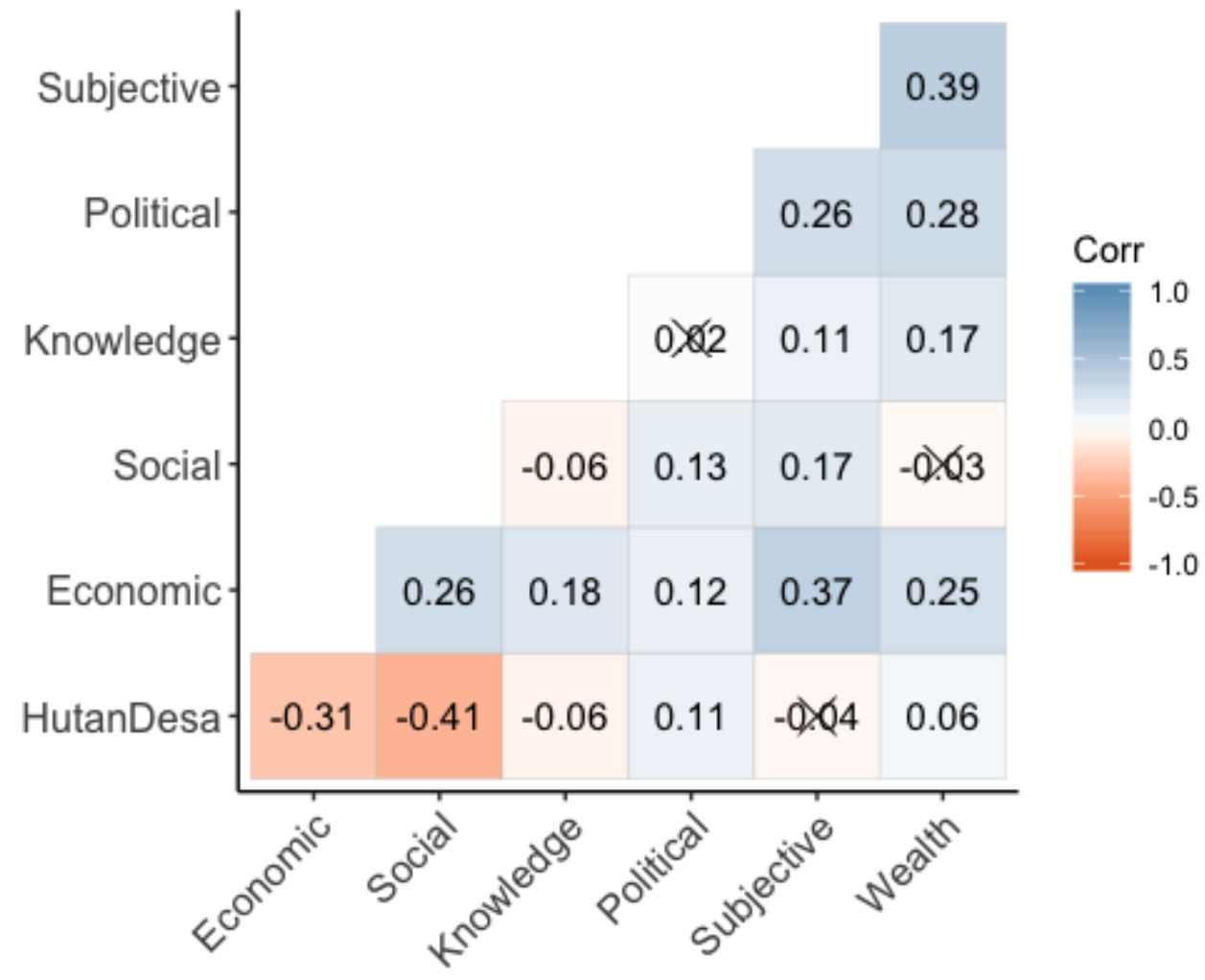

Figure A2.2. Correlation matrix to identify any existing relationships between Hutan Desa and wellbeing metrics that might have some bearing on participation or forest use. Knowledge, economic, and social wellbeing were all negatively correlated to Hutan Desa. Political wellbeing is positively correlated to Hutan Desa, which is reasonable considering it is calculated based on tenure and access to media communication. 